\title{
齐东来 学位論文審査要旨
}

$\begin{array}{cccc}\text { 主査 汐 } \text { 田 剛 } & \text { 史 } \\ \text { 副主查 佐 } & \text { 藤 } & \text { 建 } \\ \text { 同 } & \text { 押 } & \text { 村 } & \text { 光 雄 }\end{array}$

\section{主論文}

Human chromosome 5 carries a transcriptional regulator of human telomerase reverse transcriptase (hTERT)

（ヒト5番染色体上にはTERTの転写を制御する遺伝子が存在する）

（著者 : 齐东来、大平崇人、押村光雄、久郷裕之）

平成22年 Biochemical and Biophysical Research Communications

398巻 695頁 701頁 


\section{学 位 論 文 要 旨}

\section{Human chromosome 5 carries a transcriptional regulator of human telomerase reverse transcriptase (hTERT)}

（ヒト5番染色体上にはTERTの転写を制御する遺伝子が存在する）

がんの発生・進展においてTERT遺伝子とテロメレース活性は非常に重要な役割を担って いる。本研究では、ヒトメラノーマ細胞株A2058 ヒト5番染色体導入によってhTERTの発現 が抑制されることを明らかにした。さらに、5番染色体はhTERTのプロモーター領域 $(-1623$ 〜-1047bp）に作用しその発現を抑制的に調節していることを見出した。また 5 番染色体導 入によるhTERTの発現抑制によりA2058細胞の増殖能が低下し、細胞老化が誘導された。

\section{方 法}

ヒト5番染色体導入には、ヒト5番染色体を保持するマウスA9細胞から微小核融合法 (MMCT) を用いてA2058細胞への導入を行った。hTERT発現レベルおよびテロメレース活性の 測定には、RT-PCRとTRAP assayにより解析を行った。細胞増殖能の評価には、population doubling time及びsaturation densityを測定し解析を行った。細胞老化の評価にはSA- $\beta$ -Gal染色法を用いた。またhTERTプロモーターへの作用の解析はルシフェラーゼ遺伝子を用 いたレポーターアッセイにより行った。

\section{結 果}

ヒト5番染色体導入によって、ヒトメラノーマ細胞A2058においてhTERT及びテロメレース 活性の抑制が認められた。一方、コントロールとしてヒト10番染色体を同じ細胞に導入し たところ、それらの発現および活性に変化は認められなかった。さらにhTERTの発現抑制が 認められたヒト5番染色体導入A2058細胞は、10番染色体導入細胞に比べ増殖速度が遅く、 著しい細胞の形態変化を呈し20PDsで細胞分裂が停止した。またレポーターアッセイの結果 から、このhTERT発現低下はhTERTプロモーターを介した遺伝子の抑制的な転写制御の結果 である可能性が示唆された。

\section{考 察}

hTERTの抑制的な発現調節に関わる因子として、プロモーター領域に作用するいくつかの 
転写因子が報告されている。しかし、5番染色体上にコードされている遺伝子の報告はなく、 本研究で同定されたhTERTプロモーター領域 $(-1623 \sim-1047 b p)$ に関わる転写調節について の報告も未だない。これらのことから、5番染色体上には新規のhTERT抑制遺伝子及び、こ の未知の遺伝子がhTERTプロモーターに作用してhTERTの転写を抑制的に制御している新規 の分子メカニズムの存在が示唆された。これらのことより親株であるA2058細胞において発 現が消失している遺伝子がその候補遺伝子として考えられた。そこでこれまでの実験デー タをもとに、発現量に著しい変化が認められる遺伝子をマイクロアレイを用いた網羅的な 解析によって検索した結果、PITX1遺伝子が5番染色体上のhTERT抑制の候補遺伝子として同 定された。興味深いことに、PITX1は、本研究で示したhTERTプロモーター領域 $(-1623$ -1047bp) だけでなくマウスのmTertプロモーター領域に直接結合することでhTERT遺伝子の 発現を抑制的に制御していることが明らかとなった。以上のことから、からPITX1遺伝子が 5番染色体上のhTERT抑制遺伝子であることが強く示唆された。

\section{結 論}

ヒト5番染色体上には、プロモーター領域に作用してhTERT遺伝子の発現を、抑制的に転 写調節する遺伝子が存在することを明らかにした。 